\title{
COVID-19 AND PRESIDENTIAL POPULARITY IN LATIN AMERICA
}

\author{
Covid-19 y popularidad presidencial en América Latina
}

Covid-19 e popularidade presidencial na América Latina

\section{PAOLO SOSA-VILLAGARCIA (D) paolo.sosa@alumni.ubc.ca ${ }^{1}$ VERÓNICA HURTADO LOZADA (1) vhurtado@alumni.ubc.ca ${ }^{1}$}

${ }^{1}$ University of British Columbia

\begin{abstract}
Keywords: presidential popularity; public opinion; policy framing; Covid-19; Latin America

\section{Abstract}

The current pandemic has challenged political leaders. As governments introduced containment policies, presidential approval in several countries started to rise. This phenomenon brought back discussion of the rally-'round-the-flag effect, which refers to the public's propensity to put aside political differences and support presidents during episodes of international crises. By focusing on four Latin American presidents, we analyze such an effect and the conditions that mediate it, considering its significant variation in the region. We propose that the change in presidential popularity is short-lived and ultimately conditioned by the timing and stringency of the policy responses, the pandemic's framing, and the opposition's opportunities for policy criticism.
\end{abstract}




\section{Palabras clave:} popularidad presidencial; opinión pública; enmarcamiento de políticas; Covid-19; América Latina

\section{Palavras-chave:} popularidade presidencial; opinião pública; enquadramento de políticas; Covid-19; América Latina

\section{Resumen}

La pandemia actual ha planteado importantes desafíos a los líderes políticos. A medida que los gobiernos introdujeron políticas de contención, la aprobación presidencial comenzó a subir en distintos países. Este fenómeno trajo de vuelta la discusión sobre el efecto "rally-'round-the-flag", es decir la tendencia de los ciudadanos a dejar a un lado las diferencias y apoyar a los gobiernos de forma unánime en los momentos de crisis. Al centrarnos en cuatro presidentes latinoamericanos, analizamos dicho efecto y las condiciones que lo median, considerando su variación significativa en la región. Luego, proponemos que, en última instancia, los cambios en popularidad son efímeros y están condicionados por la rigurosidad y prontitud de la respuesta, como se ha enmarcado o presentado la misma, y las oportunidades de la oposición para criticarla.

\section{Resumo}

A atual pandemia apresentou desafios significativos para os líderes políticos. À medida que os governos introduziram políticas de contenção, a aprovação presidencial começou a aumentar em diferentes países. Este fenômeno reacendeu a discussão sobre o efeito "rally-'round-the-flag". ou seja, a tendência dos cidadãos de colocar as diferenças de lado e apoiar os governos de forma unânime em tempos de crise. Ao nos concentrarmos em quatro presidentes latino-americanos, analisamos esse efeito e as condições que o mediam, considerando sua variação significativa na região. Propomos, em suma, que as mudanças na popularidade são efêmeras e condicionadas pelo rigor e rapidez da resposta, pelo seu enquadramento e pelas oportunidades para a oposição criticá-la.

\section{INTRODUCTION}

At first glance, the Covid-19 pandemic appears to have boosted national leaders' popularity around the globe. In places like Canada, Germany, India, and even the United States ${ }^{1}$, journalists and scholars revisited the "Rally-'round-the-Flag" effect literature to make sense of the spike in the popularity of leaders ${ }^{2}$. The rally effect refers to the public's propensity to put aside political differences and support presidents during episodes of international crises (Baker \& Oneal, 2001), and has been used to describe the increase in popularity of U.S. presidents during wartime. Given this literature, we would expect that all national leaders experience an increase in their popularity in the months following the pandemic. However, this is not the case.

While traditional rally effects explanation highlights the role of patriotism as the driving mechanism (Murray, 2017), this does not seem to work in the context of the pandemic. Preliminary survey research in Europe shows that containment

1. The Economist (2020).

2. See, for example, The Economist (2020), Lira (2020), and Shaw (2020). 
measures and pandemic dynamics mediate the effect of patriotism in political support. People's attitudes towards pandemic containment measures activate feelings of patriotism, but this only occurs when the government requires citizens to follow mandatory social distancing in the form of lockdowns (Bol et al., 2020). Citizens also develop feelings of patriotism as a response to the threat of the pandemic, and this only occurs as contagion and mortality rates increase dramatically, and the threat perception increases (Schraff, 2020). We extend this literature by analyzing patterns of presidential popularity in developing countries and introducing three mediating mechanisms.

In contrast to previous studies, we argue that presidential popularity during the pandemic is not a manifestation of patriotism but the result of policy choices. Using the cases of Brazil, Chile, Mexico, and Peru, we find that the pandemic has not affected all presidents equally. Presidential popularity increased with the introduction of policy responses to the pandemic, and we propose three conditions that could be mediating the effect: (1) stringency of the response, (2) framing of the containment measures, and (3) opportunities for the opposition to criticize them. Yet, following changes in popularity trends in these cases shows that the effect of the pandemic on presidential popularity -either negative or positive- is shortlived and could be easily reversed.

We aim to extend the study of the political effects of the pandemic in developing countries. Studies in this context have focused on the effects of the pandemic on social mobilization, elections and social services provision. We complement those efforts by showing that the pandemic has also provided an opportunity for national leaders to boost their popularity, which can promote stability and more ambitious policies in the country. Therefore, our analysis is a first step into the study of the effects of the pandemic on the political class.

\section{RALLY-'ROUND-THE-FLAG}

The "Rally-'round-the-Flag" effect was first described when analyzing presidential ratings during war periods in the United States (see Mueller, 1973). As the name suggests, presidential popularity boosts in contexts of external threat occur when political leaders use patriotism to mobilize public opinion (Murray, 2017). In such a model, citizens support the President -despite their differences- to confront the common, external enemy. More importantly, the political opposition is not critical of the president's measures. This could be the case because they agree with his measures, they consider the external enemy more dangerous, or they calculate that opposing the government will evoke massive rejection.

However, as we have seen, presidents during the pandemic have faced different fates: while some have increased their popularity, others have remained 
unaffected by the pandemic. Preliminary studies in Europe have advanced in nuancing the role of patriotism and opinion leadership, focusing on studying the "lockdown" effect produced directly by the policy response. Using evidence from a web-based survey applied to citizens in 15 Western European countries, Bol et al. (2020) found that lockdowns were the main driver of supportive opinion for governments. In other words, the use of drastic measures creates the feeling of a national emergency which, in turn, motivates support for the government that implements them.

Methodologically, the study takes advantage of the timing of the survey and the introduction of lockdowns within it, which created quasi-experimental control and treatment groups with those surveyed before and after the introduction of such containment measures. On average, those interviewed after the introduction of the lockdown were more willing to vote for the incumbent party, more supportive of the government, and even more satisfied with democracy. The effect was not directly created by the external threat and patriotic rallies, but by the introduction of containment measures. While news about the pandemic's potential effects were already known, it was the measure in itself that created the effect.

Following a similar quasi-experimental research strategy, Schraff (2020) uses a regression discontinuity design to analyze data gathered by a household survey in the Netherlands with similar conditions creating treatment and control groups. In this study, Schraff (2020) finds no evidence supporting the claim that lockdown effects are causing changes in political support to authorities and institutions. Instead, the study finds a statistically significant relation between pandemic dynamics and citizen's increase in political support. In short, the increase of intensity of the outbreak shapes greater favorable opinions among citizens. The greater the perceived threat, the stronger the positive reaction towards the government. The study concludes that the perceived collective threat is the main driver of changes in public opinion.

For Latin America, Klobovs (2020) analyzed the effect of the pandemic on presidential approval in Argentina. Using individual-level survey data on presidential approval, he finds that citizens' evaluation of the fight against coronavirus has the most impact on President Alberto Fernandez approval. His analysis also shows that those who voted for the opposition candidate are $34 \%$ more likely to support the President after the installment of the lockdown. The author claims that this change in support provides preliminary evidence for the Rally-'round-the-Flag effect working in Argentina.

In our study, we focus on how containment policies affect presidential popularity in Latin America. Changing the unit of observation, we analyze the crossnational variations observing that containment policies seem to correlate with in changes on presidential popularity. This change of perspective allows us to focus on institutional and political features that substantively vary between countries, 
something that has not been accounted for when analyzing individual responses. We propose three conditions that shape presidential approval after the pandemic: the timing and stringency of the policy responses, the framing of the pandemic, and the opposition's opportunities for policy criticism.

\section{DATA AND METHODS}

We analyze the relationship between the pandemic crisis and presidential popularity through a cross-national comparison with a multi-method approach. In contrast to Bol et al. (2020) and Schraff (2020), we do not use individual-level data but focus our attention on variations in aggregate data at the national level to identify divergent conditions that account for popularity trends. Using this framework, we propose the following four hypotheses:

- $\quad H 1$ : The pandemic shock is correlated with an initial increase in presidential popularity.

- H2: Countries that implement more stringent containment measures experience higher rates of presidential popularity after the pandemic than those with less stringent measures.

- H3: Countries with leaders who frame the pandemic as a national crisis experience higher rates of presidential popularity after the pandemic than those with leaders who minimize the pandemic.

- H4: Countries with weak and fragmented oppositions experience higher rates of presidential popularity after the pandemic than countries with strong and coordinated opposition.

In terms of data collection, we focus on popularity measures for four Latin American presidents: Jair Bolsonaro (Brazil), Sebastian Piñera (Chile), Andres Manuel López Obrador (Mexico), and Martin Vizcarra (Peru). Information about presidential popularity for our cases is measured through different national-level opinion polls reports ${ }^{3}$ (See Appendix for details on the sources). For our independent variables, we gathered information from secondary sources. The timing and stringency of the containment measures come from the Oxford Covid-19 Government Response Tracker. Country-level data on Covid-19 contagion dynamics comes from the Inter-American Development Bank's Coronavirus Outbreak Dashboard.

3. The data on approval ratings was collected directly from opinion polls reports (January 2019 to June 2020), except for Mexican polls which were collected through the Oraculus.mx platform. Finally, historic opinion data for Peru (1990-2020) was reconstructed using the reports by Ipsos-Peru. 
Information on the countries' political configurations was collected using indexes from the Varieties of Democracy Project. Finally, information on policy framing and current political events was collected through the British Broadcast Corporation's coverage of Latin American politics.

\section{Analysis}

Our analysis employs two methodological strategies. First, we test our H1 by conducting a difference in means test between presidential approval rates before and after the beginning of the pandemic. This allows us to estimate the average effect of the crises on presidential popularity and works as our dependent variable. Second, we conduct a qualitative cross-national comparison between our four cases to test for $\mathrm{H} 2, \mathrm{H} 3$, and $\mathrm{H} 4$.

Our difference in means test shows the variation on presidential popularity in four Latin American countries in the months before and after the Covid-19 pandemic. We compare subsets of observations divided in two periods of time; this division is created by the introduction of a treatment, which in this case is the Covid-19 pandemic. This is measured as a dichotomous variable $(0=$ pre outbreak; 1 = post-outbreak) where all months after the start of the pandemic are considered "under treatment". The first subset (or pretest group) clusters observations before the intervention, working as a baseline or counterfactual for the comparison exercise. The second subset -which groups observations after the intervention- shows information about the change (see Lewis-Beck et al., 2004, 516).

We use this method to provide estimations of the effect given the exogeneity and as-if random nature of the condition creating the crisis. We make this assumption since the detection of first infected cases occurred in the same timeframe for all cases. More importantly, the severity of the outbreak in each country was not fully anticipated given the lack of consistent information at the beginning of the pandemic. This was not unique for Latin America, but part of a global trend (see Lancet 2020). Although containment policies were able to control infection rates in the following weeks, the starting point in all countries was uncontrolled.

For this design, we use Ordinary Least Squares (OLS) linear regressions to show that there is significant variation in the presidential popularity trends before and after the start of the pandemic ${ }^{4}$. This exercise only accounts for the relationship between the start of the pandemic and changes in presidential popularity and

4. More importantly, other methods -such as those based on variances- require balanced observations groups, which is not possible in this case due to time constraints. See: https://www.rdocumentation.org/packages/its.analysis/versions/1.4.1/topics/itsa.model. 
does not include control variables. By design, this estimation strategy could create problems of overestimation of the direction of the effect, so we complement it by computing the volatility and directions of popularity trends using Local Regressions (LOESS) models ${ }^{5}$. Those models provide smoother trend estimations and were computed by contrasting time variations within popularity without accounting for any other variables, including the start of the pandemic. Together, both exercises provide a better picture of the kind of variation observed in popularity trends.

Second, we use cross-national comparisons to account for the effect of our independent variables: timing and stringency of the policy responses, framing of the crisis, and opportunities for policy criticism. Following this strategy, we show that the presence of the crises and the introduction of containment measures are not enough to produce the expected effect (a boost in presidential popularity), but also that contagion dynamics have important explanatory limits. This analysis is possible given important variations both in explanatory and outcome conditions.

\section{THE EFFECT ON PRESIDENTIAL POPULARITY TRENDS}

Weeks after the pandemic started, presidential popularity trends changed in our four cases of study. At plain sight, Figure 1 -comparing four months after and before the outbreak- shows divergent changes in March 2020. While Peru's Vizcarra and Chile's Piñera experienced an increase in their popularity, Mexico's Lopez Obrador and Brazil's Bolsonaro decreased in the same measure. Yet, Lopez Obrador has a prior decreasing trend with a delayed increase in April 2020, one month after the start of the pandemic. In all three other cases, previous trends seem more stable.

Our analysis partially confirms these trends. In terms of direction, OLS regressions show significant differences on the presidential popularity rates between presidents (Table 1). When analyzing the trend starting from January 2019, Vizcarra's popularity clearly increased after the start of the pandemic (25.4 per cent, on average). Meanwhile, Lopez Obrador and Bolsonaro's ratings faced an opposite fate since both presidents have seen their popularities decreased on average (-7.3 and -10.2 per cent, respectively). All these variations have high statistical significances $(<0.001)$.

5. See: http://r-statistics.co/Loess-Regression-With-R.html 
Figure 1. Presidential popularity trends and Covid-19

(November 2019 - June 2020)

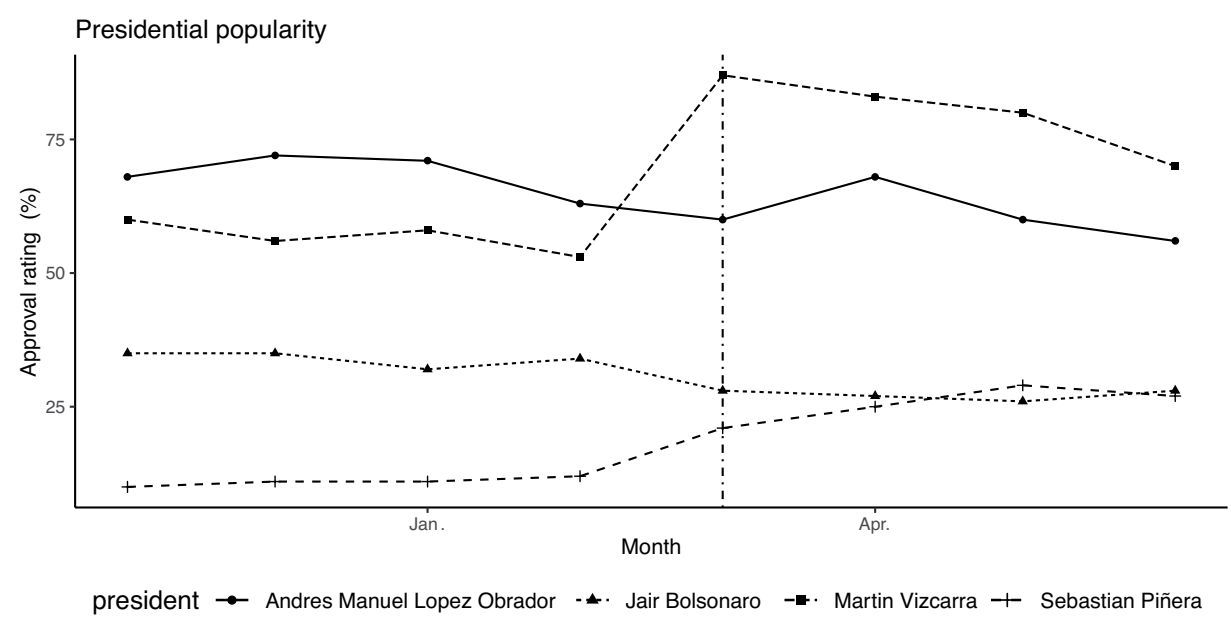

Source: Authors' own elaboration.

The case of Chilean president Sebastian Piñera is challenging for our analysis. When observing the latest polls (Figure 1), we could conclude there is an important increase in his popularity. However, the OLS regression coefficients comparing scores from January 2019-June 2020 suggest there is no significant variation after the start of the pandemic. Moreover, if there was some, it would be negative. Now, if we balance the number of cases and compare only four months before and after the pandemic, all changes remain the same (although López Obrador's losses significancy), but the Chilean clearly shows the positive and significant change on popularity ( 14.5 per cent, on average) that can be plainly observed in the score's evolution.

Looking at longer trends help us to understand this difference in the Chilean case. The LOESS model shows a reversing trend in the southern country (Figure 2). While there is an important increase on average, it occurs as a recovery rather than as a boost. We can see the increase in detail zooming in the four months before and the four months after the beginning of the pandemic. If our analysis is limited to this timeframe, the change in presidential popularity trend is significant. However, this is masking the effect of the 2019 social mobilization, also known as "El Estallido". This mobilization against the government negatively affected Piñera's popularity. Since the start of 2020, Piñera's popularity might have been going back to "normal". Yet it was in March, with the start of the pandemic, that the declining trend was reversed. 
Table 1. Variation of Covid-19 effects on presidential popularity (OLS models)

\begin{tabular}{lccc|ccc}
\hline Formula & \multicolumn{5}{c}{ Approval $=\alpha+$ Covid19 ${ }^{*} \beta+\varepsilon$} \\
\hline Time frame & \multicolumn{3}{c}{ November } & 2019-June 2020 & \multicolumn{3}{c}{ January } & 2019-June 2020 \\
\hline Observations & \multicolumn{2}{c}{8 months (4 under treatment) } & \multicolumn{2}{c}{ 18 months (4 under } & treatment) \\
\hline President & Coefficent & $p$ & R2 & Coefficent & $p$ & R2 \\
\hline Bolsonaro & -6.75 & $* * *$ & 0.9124 & -7.25 & $* * *$ & 0.6153 \\
López Obrador & -7.50 & & 0.4737 & -10.21 & $* *$ & 0.3587 \\
Piñera & 14.50 & $* * *$ & 0.9191 & -1.50 & & 0.0035 \\
Vizcarra & 23.25 & $* *$ & 0.8541 & 25.36 & $* * *$ & 0.6004 \\
\hline
\end{tabular}

Significance codes: ${ }^{* * *} p<0.001 ;{ }^{* *} p<0.01 ;{ }^{*} p<0.05, \dagger p<0.1$.

Source: Authors' own elaboration.

Figure 2. Presidential popularity trends and Covid-19 (2019-20), LOESS regression models
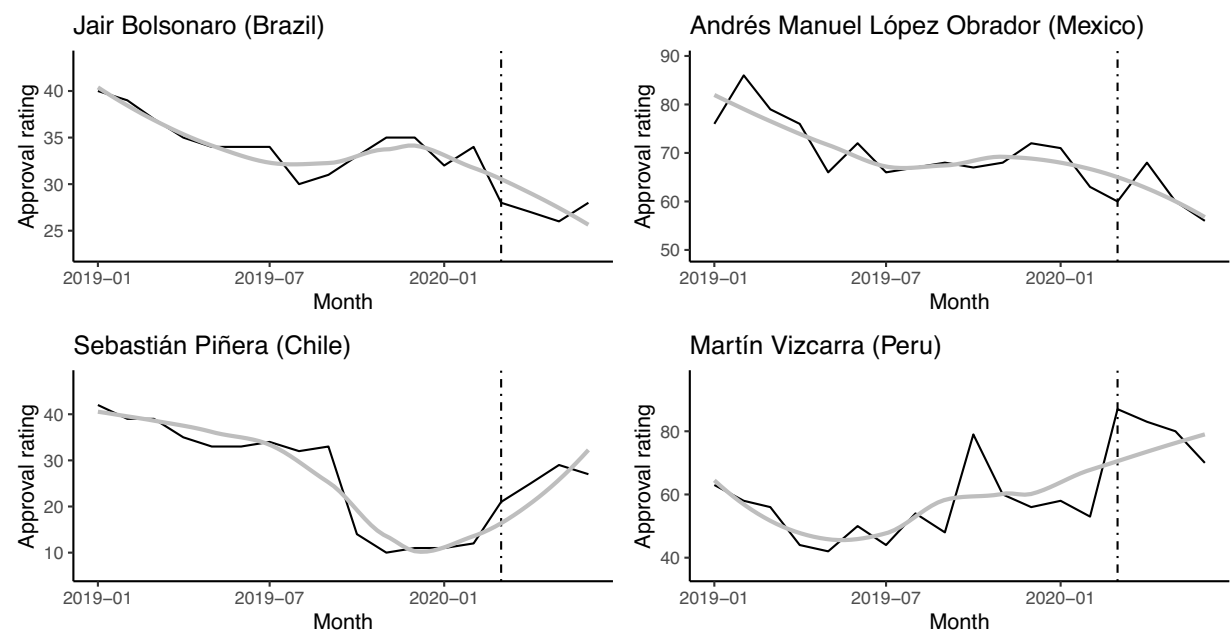

Source: Authors' own elaboration. 
In the cases of Bolsonaro and López Obrador, the trends of presidential popularity seem to be following pre-pandemic trends. Ratings do not fluctuate significantly, with small variations from month to month. On the contrary, Vizcarra's ratings are much more volatile, with an important peak in the second half of 2019. Such peak was attributed to the public support to the dissolution of parliament in September 2019. Contrasting with the Chilean case, the effect of that political crisis was already normalizing when the outbreak started in the region, creating the space for a better assessment of the pandemic's impact on presidential popularity ratings in the following months.

The same trends are identified in presidential unpopularity. The interrupted time series analysis using OLS regression models show similar variations in disapproval rating's changes (Table 2). On the one hand, the unpopularity of president Vizcarra significantly decreases on 17.8 per cent on average, while presidents Bolsonaro and López Obrador have seen their disapproval ratings increasing in around 9 percent since March 2020. On the other hand, the ratings for president Piñera have increased but in a smaller volume and with no statistical significance for such change. When zooming on the eight-months' time frame, we observe a similar pattern than in the case of popularity scores.

Table 2. Variation of Covid-19 effects on presidential unpopularity (OLS models)

\begin{tabular}{lcccccc}
\hline Formula & \multicolumn{5}{c}{ Disapproval $\alpha+$ Covid19 ${ }^{*} \beta+\varepsilon$} \\
\hline Time frame & \multicolumn{2}{c}{ November 2019 -June 2020} & \multicolumn{2}{c}{ January 2019-June 2020 } \\
\hline Observations & \multicolumn{2}{c}{8 months (4 under treatment) } & \multicolumn{2}{c}{18 months (4 under treatment) } \\
\cline { 2 - 6 } President & Coefficent & $p$ & $R 2$ & Coefficent & $p$ & R2 \\
\hline Bolsonaro & 6.00 & $* *$ & 0.8182 & 9.64 & $* *$ & 0.3669 \\
López Obrador & 6.25 & & 0.4009 & 9.11 & $*$ & 0.3122 \\
Piñera & -18.25 & $* * *$ & 0.9450 & 1.75 & & 0.0030 \\
Vizcarra & -15.75 & $* *$ & 0.7658 & -17.82 & $* *$ & 0.4787 \\
\hline
\end{tabular}

Significance codes: ${ }^{* * *} p<0.001 ;{ }^{* *} p<0.01 ;{ }^{*} p<0.05, \dagger p<0.1$.

Source: Authors' own elaboration. 
Figure 3. Presidential unpopularity trends and Covid-19 (2019-20), LOESS regression models
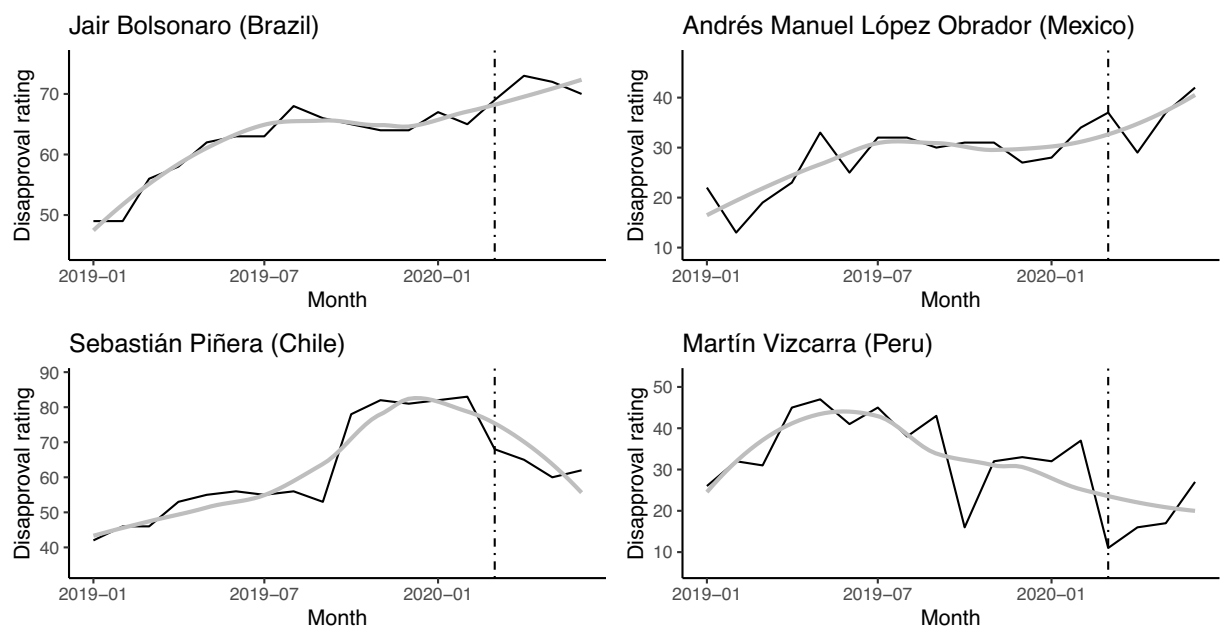

Source: Authors' own elaboration.

In that sense, LOESS models do not differ. Smother trends are observed for the unpopularity of presidents in Brazil and Mexico, while Peru's presidential disapproval ratings are more volatile. Moreover, the recovery trend is also observed for Chile's Sebastián Piñera. More importantly, by mirroring the results for approval ratings, unpopularity trends show consistency in the differentiated effect created by the pandemic. While all four countries faced the challenges of containing the Covid-19 pandemic, the presidents' performance has been valued in different ways. While the outbreak has been followed by positive changes for president Vizcarra, the consequences were not as favorable for the others.

Therefore, our analysis does not find evidence that supports $\mathrm{H} 1$, which proposes that the pandemic is correlated with an increase in presidential popularity. In contrast, we find that the pandemic has not affected the presidential popularity trends in these countries equally. While Vizcarra's approval was boosted by the pandemic, Piñera's only recovered after months of social mobilizations against his administration. In the cases of Brazil and Mexico, we observe a declining trend that is catalyzed by the start of the pandemic. In the next section we explore three possible explanations for this variation. 


\section{EXPLAINING VARIATION}

How to explain variation in these changes on presidential popularity? As we have seen, explanations turned to the "Rally-'round-the-Flag" effect to explain the initial boost on presidential popularity due to the pandemic. We use this framework and propose that, in the context of the pandemic, three mechanisms are at play: the timing and stringency of the policy responses, the framing of the pandemic, and the opposition's opportunities for policy criticism.

Policy responses do seem to correlate with different popularity outcomes. However, contrary to Bol et al. (2020), we find that the introduction of lockdowns is not similarly experienced in Latin American countries and does not immediately lead to an activation of patriotism feelings. Instead, we propose that the stringency and timing of the containment measures mediate the effect we observe.

Figure 4 shows the evolution of the stringency of containment measures in our four cases and highlights the initial difference in scores. While countries eventually reach similar levels of stringency, the first weeks after the first case is identified show the difference between countries approach to the pandemic. Peru, the country with the earliest stringent response, shows a clear positive increase in the approval rating. Mexico, on the opposite side, shows no clear change. Moreover, similar responses in the cases of Brazil and Chile (11 out of 100) were followed by different presidential approval and disapproval ratings trends. As a result, we do not find conclusive evidence for our $\mathrm{H} 2$.

Figure 4. Evolution of stringency of Covid-19 responses in March, 2020

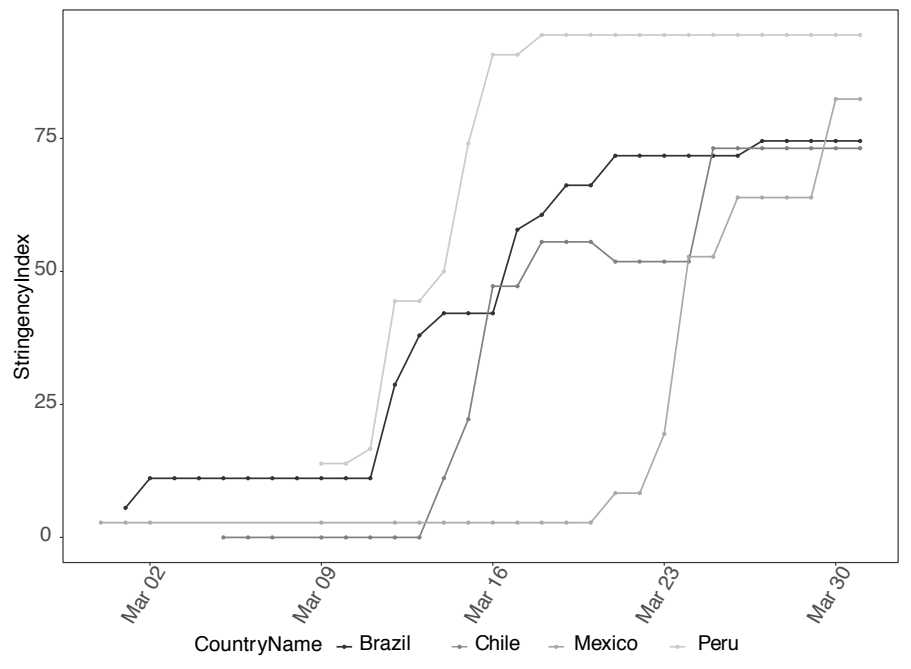

Source: Hale et al. (2020). 
Stringency of the measures could present mixed results because of the pandemic dynamics. As Figure 5 shows, neither the growth in number nor the volume of cases seem to be in relation to popularity trends. Although Brazil's higher cumulative number of cases could suggest some relation, the case of Peru-second at contagion rates and first in popularity growth- contradicts it. Both cases have been internationally highlighted for the disastrous effects of the pandemic on their societies, yet they clearly diverge in presidential popularity ratings ${ }^{6}$. Moreover, the relation between the contagion dynamics and approval ratings evolution is not statistically significant, neither within nor between countries.

Figure 5. Presidential popularity and Covid-19 contagion dynamics (2020)

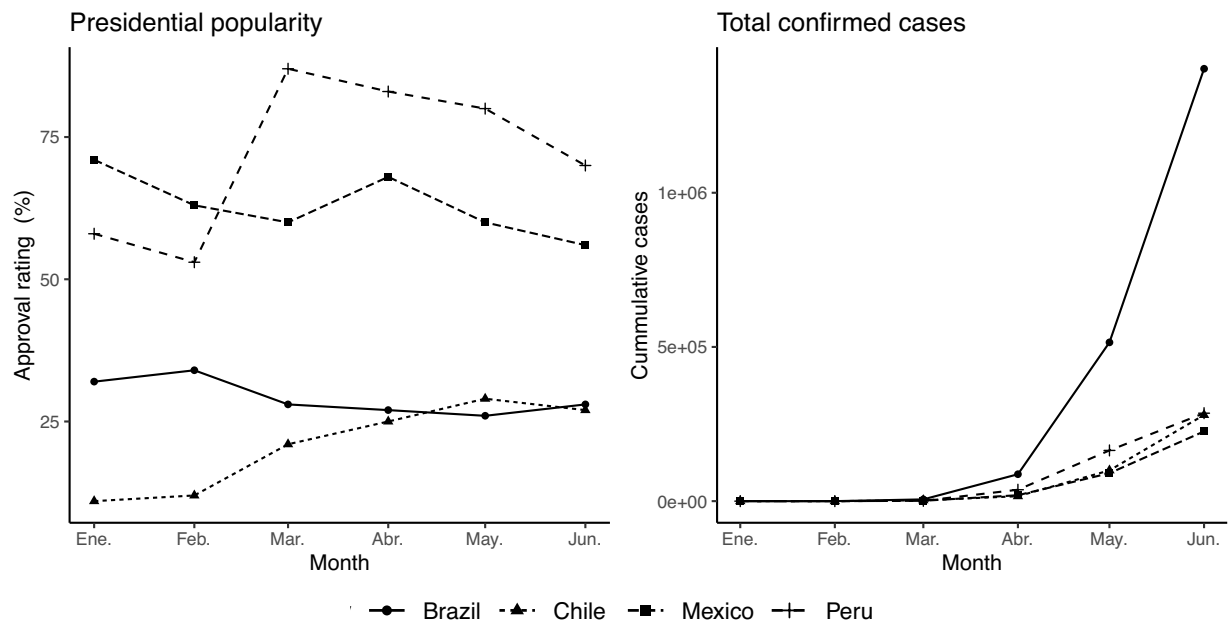

Source: Cadem (2020); Ipsos-Perú (2020); Oraculus (2020); XP Investimentos (2020); Inter-American Development Bank (2020).

Instead, we should analyze the evolution of presidential popularity as a result of the interaction between the severity of the pandemic and the policy response ${ }^{7}$. To address this interaction, we leverage the governments' public discourse about the pandemic, and test out H3. The policy framing of the containment measures captures the sense of urgency in response to the evolution of COVID-19 in the country and is correlated with the stringency level of the measures. This pattern could be observed in the evaluation of the government response by late March

6. See Sosa-Villagarcia (2020) and Welp (2020).

7. See Gallup International Association (2020). 
(Table 3). Although all four governments had stringent measures in place by that moment (Figure 4), the policy framing was different.

Chile and Brazil clearly show this difference. While these countries shared similar responses to the pandemic, we have shown that their presidential approval ratings' trends clearly differ. In Brazil, Bolsonaro's popularity decay was intensified by the pandemic. Yet this trend was also affected by political polarization and the presence of an important supporting sector (see Hunter and Power 2019). In Chile, the Covid-19 outbreak seems to have either facilitated or not affected the recovery trend after several months of consistent, high disapproval due to El Estallido. The difference is clear when contrasting policy framing.

Table 3. Evaluation of governments' response to the pandemic in late March (\%)

\begin{tabular}{lcccc}
\hline Perception & $\begin{array}{c}\text { Bolsonaro } \\
\text { (Brazil) }\end{array}$ & $\begin{array}{c}\text { López Obrador } \\
\text { (Mexico) }\end{array}$ & $\begin{array}{c}\text { Piñera } \\
\text { (Chile) }\end{array}$ & $\begin{array}{c}\text { Vizcarra } \\
\text { (Peru) }\end{array}$ \\
\hline Good & 29 & 41 & 43 & 83 \\
Bad & 44 & 45 & 48 & 16 \\
Regular & 21 & 9 & n.a & n.a \\
No opinion & 6 & 5 & 9 & 1 \\
Total & 100 & 100 & 100 & 100 \\
\hline
\end{tabular}

Source: Cadem (2020); Ipsos-Perú (2020); Oraculus (2020); XP Investimentos (2020).

In the case of Brazil, president Bolsonaro has failed to convince an important segment of the citizenry that his policy response is the adequate. More importantly, in his presidential address of the pandemic, the president has continuously minimized the severity of the threat, despite the fact global information suggested the opposite (Lasco, 2020). In doing so, the president has created conflicts with other political and public authorities, which has even included clashes with members of his cabinet. This situation could be also conditioned by polarization. If policy-framing is important, it could be also importantly nuanced by the presence of a precedent political divide where faithful supporters allying their preferences to favor the president (Smith, 2020; Crayne and Medeiros, 2020).

Despite similarities in stringency evolution, Piñera's framing of his policy response and the severity of the health crisis clearly differs. While it is true that the president clearly underestimated the potential impact of the outbreak in the country, his public statements never challenged the globally shaped perception of threat. In other words, the president overestimated the preparedness of the Chilean state without resting importance to the pandemic (Castiglioni, 2020). This 
clearly differed with Bolsonaro's justification for the lack of stringent measures. Consistently, the Chilean president changed the course of the policy response by mid-March, which came along with a recognition of the initial mistake, both strengthening quarantine measures and constitutionally framing the crisis as a "national catastrophe" (Fuentes, 2020).

Finally, we test our $\mathrm{H} 4$ by looking at the political conditions that shape the oppositions' behavior. All four countries showed important political divisions in recent electoral processes, although with different regime configurations and party organization levels. However, the puzzle arises when we focus on the clear distinct popularity trend observed in Peru. These differences could be observed using VDem indexes (Coppedge et al., 2020). Altogether, these configurations account for different levels of opportunity for the opposition to express and channel their opposition to the government's policies (Table 4), which, in turn, could condition the citizen's evaluation of the president's performance.

Table 4. Opposition opportunities according to V-Dem indexes (2019)

\begin{tabular}{lcccc}
\hline & $\begin{array}{c}\text { Liberal } \\
\text { democracy }\end{array}$ & $\begin{array}{c}\text { Party } \\
\text { institutionalization }\end{array}$ & Presidentialism $^{10}$ & $\begin{array}{c}\text { Divided party } \\
\text { control }^{11}\end{array}$ \\
\hline Brazil & 0.51 & 0.73 & 0.17 & 1.12 \\
Chile & 0.76 & 0.96 & 0.05 & 1.15 \\
Mexico & 0.49 & 0.84 & 0.29 & -1.17 \\
Peru & 0.67 & 0.46 & 0.11 & 1.34 \\
LA\&C & 0.47 & 0.64 & 0.35 & 0.51 \\
\hline
\end{tabular}

Source: Coppedge et al. (2020).

First, despite their political crises, Chile and Peru recorded better liberal democracy ratings in 2019, while Mexico and Brazil ranked worse, closer to the

8. This index ranks cases between 0 and 1, where higher values indicate more democratic regimes.

9. This index ranks cases between 0 and 1, where higher values indicate more institutionalize party systems.

10. This index ranks cases between 0 and 1 but is inverted in the sense that lower values represent concentrated but democratic configurations, while higher levels show less democratic ones.

11. This index ranks cases between negative and positive values. Positive values show a divided configuration, while negative values account for unified government where a single party controls the executive and legislative branches. 
region's average ${ }^{12}$. These configurations relate to the observed variation on popularity trends. However, we should expect a different direction. Healthier democracies should offer better institutional spaces for political opposition, increasing the citizen's criticism (Mainwaring, 2009, 350-357). However, beyond institutional configurations, these countries show different levels of party competition.

Accordingly, party institutionalization indexes show that Peru has distinct level of political organization through weak political parties. The weakness of political parties in this case has created a vacuum for the opposition to present credible leadership alternatives. As a result, in the face of a pandemic, the national official leader, the President, experiences an increase in popularity.

Finally, while all four countries are democratic presidential systems, they also differ in terms of how divided the government between the executive and legislative branches is. While Brazil and Chile have similar degrees of divided government configurations, Peru stands a case of important division while Mexico is clearly a case of unified government where the same party controls both powers.

Therefore, Peru's distinct pattern must be considered as a partial result of the low opportunities for the opposition to criticize containment measures. This is, however, also part of a conjunctural configuration. Politically, the main opposition forces were clearly weakened after the political crises motivated by the divided government dynamic between 2016 and 2018 (Ponce de León and Garcia, 2019).

Institutionally, this crisis also resulted in the constitutional dissolution of parliament in September 2019, limiting the institutional constraint of the opposition on the executive (Paredes and Encinas 2020). The new parliament was installed on March 16th, with the quarantine and lockdown policies already in place. Moreover, president Vizcarra enjoyed a long period where media criticism was nearly absent. These situations clearly contrast with the three other governments, which -despite variations - still face important political and institutional opposition.

\section{CONCLUSION}

Popular presidents have more capacity to persuade other political actors to adopt administration priorities and policies as their own, and they are more likely to present bold and ambitious policy. In our study, we find that the popularity of the four Latin American presidents under analysis has changed considerably since the beginning of the Covid-19 pandemic. Presidential popularity, however, has not

12. There is, however, an important difference in trends. When observing democratic ratings in the past decade, Brazilian democracy has been clearly eroded since 2016, while Mexican democratic ratings have been maintained in similar levels since the transition to democracy. 
changed uniformly in the four cases. While the popularity scores of the Peruvian president increased rapidly, we find that Chile, Brazil and Mexico present more nuanced changes in presidential approval after the beginning of the pandemic.

We have linked the variation in presidential approval after the pandemic to three possible factors: timing and stringency of the measures, policy framing and the role of the opposition. These mediating factors help explain why we observe such a stark variation between four cases that experienced the beginning of the pandemic at the same time.

Nevertheless, some caveats in our argument are necessary. On the one hand, we cannot conclude how lasting these effects will be. Recent changes in popularity trends suggest the effect to be ephemeral. Both Bolsonaro and López Obrador were able to improve their ratings in the following months. More importantly, our analysis of these four cases shows that initial policy and political mistakes could be corrected or nuanced with better framing; and recent polls in cases like Peru also show that framing could fall short when structural conditions intensify the pandemic's effect.

These conclusions are limited to the exploratory nature of this exercise. Future research on the effects of the pandemic on presidential approval will require more sophisticated methods to identify the micro foundations behind the citizens' perceptions. We assume that information and threat perceptions are equal in all countries, and not affected by previous political dynamics. However, recent research in other countries suggest that people's perceptions of the severity of the pandemic could be also shaped by parties and politicians (Lasco, 2020). The specific causal relation and mechanisms linking policy framing and opposition opportunities will also require further comparative research. For now, we have identified the explanatory potential of such conditions in this puzzle.

\section{REFERENCES}

Baker, W. D., \& Oneal, J. R. (2001). Patriotism or opinion leadership? The nature and origins of the "rally 'round the flag" effect. Journal of Conflict Resolution, 45(5), 661-687. https:// doi.org/ 10.1177/0022002701045005006.

Bol, D. et al. (2020). The effect of COVID-19 lockdowns on political support: Some good news for democracy? European Journal of Political Research. Advanced online publication. https://doi.org/ 10.1111/1475-6765.12401.

Castiglioni, R. (2020). La batalla de Chile contra el "Covid-19". Agenda Pública El País. Retrieved from www.agendapublica.elpais.com/la-batalla-de-chile-contra-el-covid-19/.

Crayne, M., \& Medeiros, K. (2020). Making sense of crisis: Charismatic, ideological, and pragmatic leadership in response to COVID-19. American Psychologist. Advanced online publication. https://doi.org/ 10.1037/amp0000715. 
Fuentes, C. (2020). Chile: Cambio constitucional, crisis social y coronavirus. Agenda Pública El País. http://www.agendapublica.elpais.com/ chile-cambio-constitucional-crisis-social-y-coronavirus/.

Gallup International Association (2020). The Coronavirus: A vast scared majority around the world. Snap poll in 28 Countries. http://www.gallup-international.com/wp-content/uploads/2020/03/GIA_SnapPoll_2020_COVID_Tables_final.pdf.

Hunter, W., \& Power, T. (2019). Bolsonaro and Brazil's illiberal backlash. Journal of Democracy, 30(1), 68-82. https://doi.org/ 10.1353/JOD.2019.0005.

Klobovs, L. (2020). El impacto del coronavirus en la figura presidencial argentina. Revista Latinoamericana de Opinión Pública. Advanced online publication. https://doi.org/ 10.14201/rlop.23517.

Lasco, G. (2020). Medical populism and the COVID-19 pandemic. Global Public Health, 15(10), 1417-1429. https://doi.org/ 10.1080/17441692.2020.1807581.

Lewis-Beck, M., et al. (2004). Interrupted time-series design. In M. Lewis-Beck, et al. (Eds.), The SAGE Encyclopedia of Social Science Research Methods (pp. 516). Thousand Oaks: SAGE Publications.

Lira, A. (April 3rd, 2020). Una bandera contra el coronavirus: Aprobaciones presidenciales en alza en tiempos de crisis. El Comercio. Retrieved from www.elcomercio.pe/politica/ coronavirus-aprobaciones-presidenciales-en-alza-analisis-del-efecto-de-los-tiemposde-crisis-covid-19-martin-vizcarra-donald-trump-chile-peru-eeuu-argentina-noticia/.

Mueller, J. (1973). War, presidents and public opinion. New York: John Wiley \& Sons.

Murray, S. (2017). The "rally-'round-the-flag" phenomenon and the diversionary use of force. Oxford Research Encyclopedia of Politics. Online publication. https://doi.org/ 10.1093/acrefore/9780190228637.013.518.

Paredes, M., \& Encinas, D. (2020). Perú 2019: crisis política y salida institucional. Revista de Ciencia Política, 40(2), 483-510. https://doi.org/ 10.4067/S0718-090X2020005000116.

Ponce de León, Z., \& García, L. (2019). Perú 2018: la precariedad política en tiempos de Lava Jato. Revista de Ciencia Política, 39(2), 341-365. https://doi.org/ 10.4067/ S0718-090X2019000200341.

Shaw, D. (April 22 $\left.{ }^{\text {nd }}, 2020\right)$. The coronavirus "rally 'round the flag" bump and trump's 2020 campaign. The International Scholar. Retrieved from www.theintlscholar.com/ periodical/2020/04/coronavirus-rally-round-the-flag-bump-trump-campaign.

Schraff, D. (2020). Political trust during the Covid-19 pandemic: Rally around the flag or lockdown effects? European Journal of Political Research. Advanced online publication. https://doi.org/ 10.1111/1475-6765.12425.

Smith, A. E. (2020). Covid vs. democracy: Brazil's populist playbook. Journal of Democracy, 31(4), 76-90. https://www.journalofdemocracy.org/articles/ covid-vs-democracy-brazils-populist-playbook/.

Sosa-Villagarcia,P.(June18th,2020).Despiteeffort,Peru'sCovid-19responsefails.YaleGlobal Online.www.yaleglobal.yale.edu/content/despite-effort-perus-covid-19-response-fails.

Sosa-Villagarcia, P., \& Camacho, G. (2019). Gobernabilidad y control politico. El equilibrio de poderes en la reforma política. Peru Hoy, 35, 39-54. https://www.desco.org.pe/recursos/ site/files/CONTENIDO/1292/02_Sosa_Camacho_PHj19.pdf.

The Economist (May 9th, 2020). Rallying round the flag Covid-19 has given most world leaders a temporary rise in popularity. The Economist. Retrieved from www. 
economist.com/graphic-detail/2020/05/09/covid-19-has-given-most-world-leadersa-temporary-rise-in-popularity.

The Lancet (2020). COVID-19: too little, too late? The Lancet, 395(10226), 755. https://doi. org/ 10.1016/S0140-6736(20)30522-5.

Welp, Y. (2020). Perú, o la debilidad del Estado. Agenda Pública El País. http://www.agendapublica.elpais.com/peru-o-de-la-debilidad-del-estado/.

\section{DATA}

British Broadcast Corporation (2020). World: Latin America. BBC News. Retrieved from www.bbc.com/news/world/latin_america.

Cadem (2020). Plaza Pública. Retrieved from https://www.cadem.cl/encuestas/.

Hale, T. et al. (2020). Oxford COVID-19 government response tracker. https://covidtracker. bsg.ox.ac.uk/.

Instituto de Estudios Peruanos (2020). Estudios de Opinión Pública. http://www.iep.org.pe/ noticias_categorias/opinion-publica/.

Inter-American Development Bank (2020). Coronavirus Impact Dashboard. http://www.iadb. org/en/topics-effectiveness-improving-lives/coronavirus-impact-dashboard.

Ipsos-Perú (2020). Novedades y encuestas. http://www.ipsos.com/es-pe/news-and-polls/ news.

Oraculus (2020). Indicadores: Aprobación presidencial. http://https://oraculus.mx/ aprobacion-presidencial/.

XP Investimentos (2020). Histórico de Pesquisas XP. http://www.conteudos.xpi.com.br/ politica/pesquisas-xp-2/.

Coppedge, M. et al. (2020). V-Dem [Country-Year/Country-Date] Dataset v10. [Dataset]. https://doi.org/ 10.23696/vdemds20. 


\section{APPENDIX}

Table A1. National surveys

\begin{tabular}{|c|c|c|c|c|c|c|c|}
\hline President & Country & Survey & Months & $\underset{\text { (approx.) }}{\mathrm{N}}$ & $\begin{array}{l}\text { Error } \\
(95 \%)\end{array}$ & Method & Scope \\
\hline $\begin{array}{l}\text { Jair } \\
\text { Bolsonaro }\end{array}$ & Brazil & XP/Ipespe & $\begin{array}{l}\text { January } \\
2019 \text { - June } \\
2020\end{array}$ & 1000 & 3.2 & Telephone & National \\
\hline $\begin{array}{l}\text { Sebastián } \\
\text { Piñera }\end{array}$ & Chile & Cadem & $\begin{array}{l}\text { January } \\
2019 \text { - June } \\
2020\end{array}$ & 700 & 3.7 & Telephone & National \\
\hline $\begin{array}{l}\text { Andrés } \\
\text { Manuel } \\
\text { López } \\
\text { Obrador }\end{array}$ & Mexico & $\begin{array}{l}\text { El } \\
\text { Financiero }\end{array}$ & $\begin{array}{l}\text { January } \\
2019 \text { - June } \\
2020\end{array}$ & 800 & 3.4 & Telephone & National \\
\hline \multirow{4}{*}{$\begin{array}{l}\text { Martín } \\
\text { Vizcarra }\end{array}$} & \multirow{4}{*}{ Peru } & \multirow[t]{2}{*}{ Ipsos } & $\begin{array}{l}\text { January } \\
2019 \text { - } \\
\text { February } \\
2020\end{array}$ & 1200 & 2.7 & In person & National \\
\hline & & & $\begin{array}{l}\text { March } 2020 \\
\text { - June } 2020\end{array}$ & 500 & 4 & Telephone & National \\
\hline & & \multirow[t]{2}{*}{ IEP } & $\begin{array}{l}\text { January } \\
2019 \text { - } \\
\text { February } \\
2020^{13}\end{array}$ & 1200 & 2.8 & In person & National \\
\hline & & & $\begin{array}{l}\text { April } 2020 \\
\text {-June } 2020\end{array}$ & 1200 & 2.8 & Telephone & National \\
\hline
\end{tabular}

Source: Authors' own elaboration.

For Peru, we reviewed reports from two different polls, although the analysis was finally performed using data from Ipsos-Peru. The reason behind this choice is that this poll collected information for every month of 2020, while IEP's lacks information for January and March. This comparison was required since Peruvian polls changed their surveying methodology given the pandemic, going from in person interviewing to telephone-based surveys. However, the comparison between

13. No data available for January 2020. 
both results shows significant consistency, despite differences on sampling sizes and errors.

Figure A1. Peru: Ipsos and IEP polls comparison (2018-20)

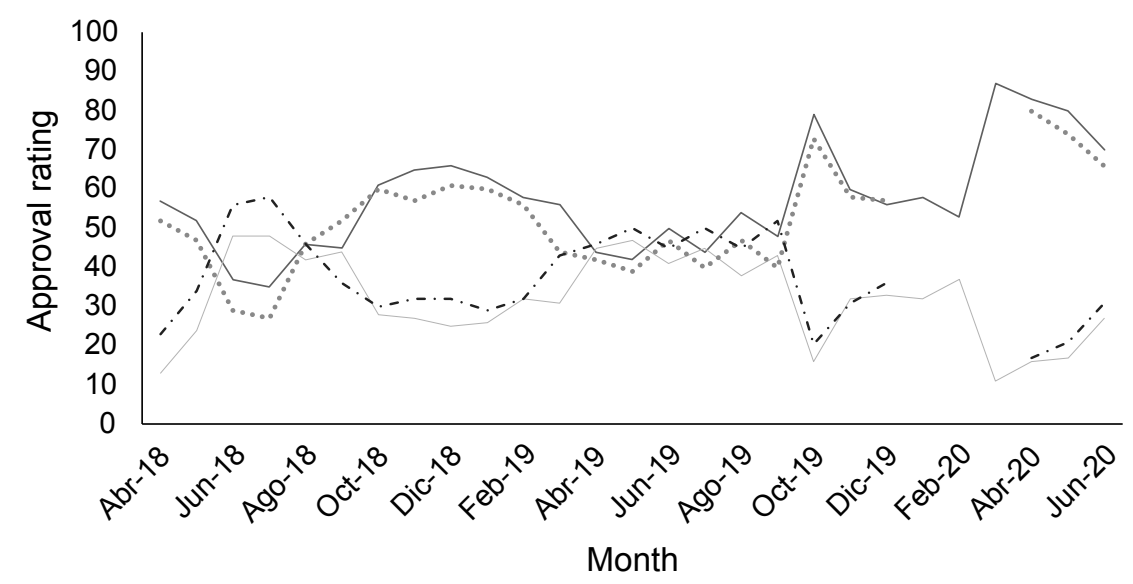

Approval -Ipsos $\quad$ Disapproval - Ipsos
$\ldots . .$. Approval - IEP
Source: Authors' own elaboration.


